\title{
School Counsellor Needs for Competency Enhancement
}

\author{
(A Multi Years Qualitative Assessment)
}

\author{
Nurbaity Bustamam*, Dara Rosita, Khairiah \\ Asfaruddin, Martunis Yahya \\ Dept. of Guidance and Counseling \\ Universitas Syiah Kuala \\ Banda Aceh, Indonesia \\ *nurbaitybustamam@unsyiah.ac.id
}

\author{
Hetti Zuliani \\ Dept.of Psychology and Counseling \\ Universiti Pendidikan Sultan Idris \\ Tanjung Malim, Malaysia \\ hettizuliani@gmail.com
}

\begin{abstract}
Every year the provincial, district or city education authorities, and other parties carry out competency improvement activities for teachers including for school counsellors. An indepth examination of school counsellor needs will help these authorities provide appropriate training which in turn can save on budget expenditures in the long run. This study aims to examine the training needs of school counsellors. The approach used is a qualitative approach with an implementation period of three years. The subjects in this study were school counsellors who were involved in trainings carried out by the provincial and district education offices for three years, which come from all over Aceh Province. The results showed that a deeper attention on skill mastery is needed rather than conceptual coverage. Recommendation for topics and method of training are discussed.
\end{abstract}

Keywords - competency enhancement, authorities training, school counselor, desired topics, meaningful methods

\section{INTRODUCTION}

Guidance and counseling are important components in the education system either in Indonesia [1] or in other countries, as stated for example in Baugh [2] and Faaz [3]. The service plays essential role in helping promoting healthy student development [2] primarily psychologically. The guidance and counseling competence is regarded as noteworthy for common teachers [4] as for special teachers who's do the job, known as school counselors. In schools, guidance and counseling services aim to help individuals gain knowledge, plan and prepare for academic progress, personal, social and career development [3].

To carry out this task, Indonesian school counselors are required to have competencies as stipulated in the regulation of the National Education Minister No. 27 of 2008 known as the standard academic qualification and competence of counselors [5]. In order to gain those competencies, school counselors are expected to have a bachelor's background in guidance and counseling [5] and continue to develop their competences through education and training as they hold the job in school. This different with requirement of school counselor from some other countries which need school counselor to have a master degree in school counseling.

To ensure in-service school counselors maintain activities of professional development, they required to report their activities to supervisor [6]. This Supervisor could be in-site supervisor, i.e., school leader or middle leaders [7], or authorities (such as district level) supervisor [8] as in Indonesian system. Furthermore, the government also support in-service school counselor development through trainings as also common teachers. Every year, education district authorities had provided various training for teachers as also provincial educational authorities, at least in Aceh Province case. Unfortunately, the current condition of school counselors, from a certain point of view, is still not as expected.

Review of researches which examined school counselor competencies generated different results. Most of the studies found that the Indonesian school counselors' competency is good, however, there were some studies which found the competencies were not fair. This conclusion perhaps limited because the scarcity of decent research about Indonesian school counselor professionalism [9]. When counselor asked to rate themselves, in general, they believe that they have the competencies needed to provide guidance and counseling services in schools, as reported in Wardhani et al. [10] and Bahri et al. [11] as Aceh province case. Likewise, if students are asked about the competence of their teachers, the research shows good results [12]. However, it was found that school counselor competencies in some points were dominantly low $[5,13]$.

This condition was not solely the problem of Indonesian school counselors. Overseas school counselors also face ambiguity and confusion about their roles in school $[14,15]$ beside avowed to be work alone as limited collaboration with other school components [16]. The ambiguity of role more than possible springs from inadequacy of competency to perform 
good work or could be the aftermath of excessive workload. There were reports stated that there is a big gap between school demand and available school counselor [17]. Excessive workload can lead to burnout, which in turn affect the evaluation of competency.

The hope that school counselors continue to improve their competency is driven, one of which is the increasing variety of problems which students may face due to the increasingly advanced world development. Therefore, authority activities to improve the competence of school counselors need to be directed to align with the needs of service targets. Assessment needs to be carried out to determine training materials and patterns that support the development of school counsellor competencies. This is proposed because especially in Aceh the development of teacher competency is largely dependent on activities carried out by the education office compared to independent self-development activities [13].

\section{METHODS}

\section{A. Research Approach}

This research was conducted to assess the learning topics and the method of training preferred by school counsellors in Aceh. A qualitative point of view was used to get and present the data.

\section{B. Participants}

Subjects of this study were school counsellors involved in trainings organized by the provincial and district education office as well as school counsellor's meetings during 2018, 2019 and 2020 which was up to 300 participants. The participant's working experience range from 2 to 25 years. Participants came from all districts in Aceh province with more number came from the Pidie, Pidie Jaya, Aceh Besar and Banda Aceh. The school levels of participants were secondary high school, senior high school and vocational high school.

\section{Data Collecting and Analysis}

The study applied group interview and discussion as the data collection method. The questions asked were about participants past experience of covered topics and the methods applied in trainings provided by authorities and also the effect of training toward their work in school. The analysis of interview data was carried out using the content analysis method.

\section{RESULTS AND DISCUSSION}

The results of the study mostly will be presented in sections A of the result and discussion part of the article, following by the proposed topics and method recommended for next training program

\section{A. Past Training Experience}

The school counsellors involved in this study stated that they have been involved in at least once yearly competency development activities provided by district, province or national education office. The interview found that the material provided in the trainings was generally about policies, need analysis instrumentation and the administrations related to service planning. Some participants stated that they were "full" of training materials, meaning that they had collected many information about what to do in school. However, they also claimed that they think they could not apply what they obtained in training into everyday work in school. The participants had common perceived assumption that the condition in the field is different than the condition proposed in training.

When participants asked about their self-efficacy in providing guidance and counseling service, at first most of them responded that they believe they are capable. This is consistent with the research conducted by Bahri et al. [11] that school counselors consider their role in school is easy to do and believe to be able to carry it out. However, when problems happen in school discussed, we discover that most participant did not use specific theory to understand student problems. Participants used or affected by lay arguments and that was why they could think that their job was easy. Participants respond to this was also that the theory they had learned is not applicable. Some of participant also stated that they feel optimistic that they will be able to apply what they had learned in trainings right after the training until sometime later. But then over time they back on doing what they usually do.

On program planning, participants conveyed that many trainings had include the topic on how to assess the need of the students and how to transform it into program planning. However, the topic usually covered one of many specific tools which requiring work with computer and/or internet. Participant claimed that even they able to use the tools, they did not use the learned instrument to produce program planning. This is consistent with Bahri [13] whom also reported that school counselor in Aceh incapable of compiling work program based on need analysis. Based on discussion found that the activity from deploying the instrument, analyze the data and transform it into program for all student under their responsibility take a lot of time and effort which they have limited.

Participants stated that they had establish guidance program in school, but the program is limited and covered very little topics. The reason for this was that many of them rarely have schedule in class. Some also get involved in other duties other than school counselor such as take care of student extracurricular activities or helping school administration. The issue here is in accordance with Havlik et al. [14], Chandler et al. [15] and Kok and Low [16] that school counselor face confusion of their role in school, do other duties and feel as to work alone because of the shortfall of support from school and shortage of human resource.

Meanwhile in doing counseling works, participant acknowledge that they tended to see the surface problem and compelled to advice the students. Most of student involved in counseling were referred by other teacher because having 
problem such as frequent escape class or involved in quarrel. Because of the pressure to solve the problem quickly, school counselor tends to take fast action such as ask student to write declaration that they will not repeat their behavior or summon student's parent to take care the problem. Counselors not even take considerable time to understand what exactly happen. From the discussion on evaluation of their counseling skills, it was found that participants face difficulties in exploring real problem. Participant also cannot decide whether student problem had emotion, cognition of behavioral basis, and because of that they had difficulties in choosing counseling techniques appropriate for problem management.

Based on discussion found that past training was lack of need assessment, merely authorities one-sided opinion or at least without completed consideration of school counselor problem in the field. Beyond that, the training method usually applied less interactive way which give less impact to participants. Participants reported being bored, task-off or engaged in other activities reticently.

\section{B. Proposed Next Training Topics and Methods}

Recommendation on topics and methods of training for school counsellor have been made based on research finding. The summary of those recommendations can be seen in table 1 .

TABLE I. TRAINING PROBLEMS AND PROPOSED RECOMMENDATIONS

\begin{tabular}{|l|l|l|}
\hline \multicolumn{1}{|c|}{ Problems } & \multicolumn{1}{|c|}{ Proposed Topic } & Proposed Method \\
\hline $\begin{array}{l}\text { Understanding the } \\
\text { problem: using lay } \\
\text { assumption on } \\
\text { problem } \\
\text { understanding }\end{array}$ & $\begin{array}{l}\text { Psychological theory on } \\
\text { how problem happen } \\
\text { with consideration of } \\
\text { developmental and socio- } \\
\text { cultural factor }\end{array}$ & Case discussion \\
\hline $\begin{array}{l}\text { Program planning: } \\
\text { lack of source in } \\
\text { doing need } \\
\text { assessment-program } \\
\text { planning }\end{array}$ & $\begin{array}{l}\text { Program planning } \\
\text { especially on useful } \\
\text { method which need } \\
\text { efficient effort and time }\end{array}$ & $\begin{array}{l}\text { Presentation, } \\
\text { discussion, and } \\
\text { small group } \\
\text { practice }\end{array}$ \\
\hline $\begin{array}{l}\text { Program } \\
\text { implementation: } \\
\text { shortage of human } \\
\text { resource }\end{array}$ & $\begin{array}{l}\text { Building team work: } \\
\text { involving school } \\
\text { members in doing } \\
\text { guidance and counselling } \\
\text { program }\end{array}$ & $\begin{array}{l}\text { Presentation, } \\
\text { discussion, and } \\
\text { small group } \\
\text { practice }\end{array}$ \\
\hline $\begin{array}{l}\text { Counselling skills: } \\
\text { ability to explore the } \\
\text { problem }\end{array}$ & $\begin{array}{l}\text { Counselling skill on } \\
\text { exploring the problem }\end{array}$ & $\begin{array}{l}\text { Modelling, } \\
\text { discussion and } \\
\text { practice }\end{array}$ \\
\hline $\begin{array}{l}\text { Counselling skills: } \\
\text { problem } \\
\text { management }\end{array}$ & $\begin{array}{l}\text { Counselling skill on } \\
\text { problem management }\end{array}$ & $\begin{array}{l}\text { Modelling, } \\
\text { discussion, and } \\
\text { practice }\end{array}$ \\
\hline $\begin{array}{l}\text { Professionalism: } \\
\text { ability to preserve } \\
\text { professionalism }\end{array}$ & $\begin{array}{l}\text { Build and maintaining } \\
\text { organizational support }\end{array}$ & $\begin{array}{l}\text { Discussion and } \\
\text { support group } \\
\text { activity practice }\end{array}$ \\
\hline
\end{tabular}

Understanding the problem of students is essential in order to provide appropriate help. When school counsellor tends to view the surface of student problem, then will be difficult to build a trusting relationship between counsellor and student which held the problem persist or even strengthen. This also important because other stake holder in Indonesian school rely on counsellor to solve student's non-academic problems [18].
School counsellor will be able to amend school climate if they have progressive view of student problems. This idea is in accordance with Helker et al. [19] that the quality of the student-teacher relationship affects students' social/emotional development, academic achievement, classroom functioning and school success.

The effectiveness of guidance and counselling service in school dependent firstly on successful implementation of needs-based programs [20]. Therefore, it is important that school counsellor able to performs need assessment which include all student under their duty. School counsellor should have general perspective on how to assess the student needs beside the ability to use many kinds of instruments. More attention should be given on the effective use of group observation and interview to cover the limit of human resource. The ability to make, find or judge efficient assessment tools also considered important.

Responding to the assessment results, school counsellor is required to implement meaningful guidance program. School counsellors need to be invited to re-identify the various developmental tasks of students in order to provide useful guidance materials whether to provide materials directly or by using information technology. For this need, the topic of training should also cover classroom management techniques and media making. The classroom management skill is important because guidance curriculum delivery centered in classroom [21].

Specifically, for counselling skills, school counsellors in Aceh still need large amount of time to develop appropriate counselling skills particularly related to problem exploration and definition as also problem management. Modelling and discussion of why specific respond is given, is important, so counsellors could understand the logic behind every respond or action. This is why the training on this this specific subject will need a lot of time if we consider it by viewing in-service school counsellor's time. This skill is central for a counselor [22] that it worth spending time.

Problems face by school counsellors perhaps is the sequence of limited support to mental health work. School counsellors in Aceh often feel that they fail to build working communication with school principals and other teachers which impact on little support physically or emotionally. Networking is important skills school counsellor should master. Many schools in Aceh only have one school counsellors, sometime this one man should responsible for more than 500 students. Common condition is one school counsellor responsible for 150 students. Exhausting is a usual effect of this condition. Good networking which means ability to perform advocacy, collaboration, take part in leadership and systemic change will help counsellor maintain healthy condition which can reduce burnout [23]. Bobik [24] also suggest specifically on interpersonal communication skills which will help school counselors emphasize position, enforce right and express expectations. 


\section{CONCLUSIONS}

The training of school counselor is needed more attention because of the role of guidance and counseling teachers in schools is important. Therefore, the implementation of the program in increasing the competence of school counselors needs to be designed according to the actual needs of the school counselors, not just based on surface assumptions. This study revealed that school counselors need more skill to understand problem, efficiently assess the need of student, provide effective guidance, explore and manage the problem in counseling student and building networking system. Next training program need to provide these topics. The desired training methods for those purposes is a maximum focus on skills than merely conceptual material.

\section{ACKNOWLEDGMENT}

We thank the leader of Aceh Provincial Education Office, Banda Aceh, Aceh Besar, and Pidie District Education Office for giving the opportunity to conduct the study in between training times. We also thank the member of Guidance and Counseling Meetings of Banda Aceh, Aceh Besar, and Langsa District as well as every school counselor involved in the 2018 until 2020 trainings for their participation in the study.

\section{REFERENCES}

[1] Y.D. Sare, N. Hidayah and D.H. Rahman, "Historical Guidance and Counseling Perspective in Indonesia", in 6th Int. Conf. on Education and Technology (ICET 2020), pp. 389-392), Atlantis Press, Dec 2020.

[2] A. Baugh, "The importance of guidance and counseling in present education system: Role of the teacher" International journal of advanced educational research, vol.3, issue 2, pp.384-386. 2018.

[3] M. Faaz, "Guidance and Counseling: An important organ of School Education," Journal of Emerging Technologies and Innovative Research (JETIR), vol. 6, issue 1, pp. 2016-2019, 2019.

[4] S.W.C. Lai-Yeung, "The need for guidance and counselling training for teachers," Procedia-Social and Behavioral Sciences, vol. 113, pp.36-43, 2014.

[5] R.S. Wijaya, W.D. Husniah, R. Taherong, C. Nuryadin, L. Hanifa and N. Ichsani "Professional competency levels teacher guidance and counseling/counselor school," IOP Conf. Ser.: Earth Environ. Sci. 235 $012105,2019$.

[6] L. Neyland-Brown, J.M. Laux, J.L. Reynolds, K. Kozlowski, and N.J Piazza, "An Exploration of Supervision Training Opportunities for School Counselors," Journal of School Counseling, vol. 17, issue 1, 2019.

[7] D.A. Bryant, Y.L. Wong, and A. Adames, "How middle leaders support in-service teachers' on-site professional learning," International journal of educational research, vol. 100, p.101530. 2020.

[8] E. Goodman-Scott, A.W. Upton, and A.A Neuer Colburn, (May 2021). "District-Level School Counseling Supervisors' Experiences With and Perceptions of Hiring School Counselors," Professional School Counseling [Online], vol. 24, issue 1, part 3, available at https://journals.sagepub.com/doi/abs/10.1177/2156759X211007656
[9] A. Awalya, A.T.D. Abdillah, E. Rifani, A. Hasna, W. Angraini, and S. Susilawati, "The level of Indonesia counselors evaluation competency," Journal of Talent Development and Excellence, vol. 12, issue 1, pp.4655-4664, 2020.

[10] N.S. Wardhani, E. Farida, and E.S. Yudha, "Profil kompetensi pedagogik dan profesional guru bimbingan dan konseling SMA di Kota Bandung [Profile of pedagogic and professional competence of high school guidance and counseling teachers in Bandung]". Indonesian Journal of Educational Counseling, vol. 3, issue 2, pp.147-154, 2019.

[11] S. Bahri, Nurbaity, M.S. Tobing, "Efikasi Diri Guru Bimbingan Dan Konseling Terhadap Kompetensinya [Self-Efficacy of Guidance and Counseling Teachers on their Competencies]," Pencerahan, vol. 13, issue 2, pp 105-13, 2019.

[12] S.S. Rosa, M. Marjohan, A. Said, "Persepsi Siswa tentang Kompetens Profesional Guru Bimbingan dan Konseling [Students' Perceptions of the Professional Competence of Guidance and Counseling Teachers]," Konselor. Vol. 3, issue 1, pp. 7-11, 2016.

[13] S. Bahri, "Studi Evaluasi Kinerja Guru Bimbingan Dan Konseling D Sekolah [Performance Evaluation Study of Guidance and Counseling Teachers in Schools]," Pencerahan, vol.14, issue 1, pp 39-61, 2020.

[14] S. Havlik, M. Ciarletta, and E. Crawford, (May 2019), "If we don't define our roles, someone else will": Professional advocacy in schoo counseling," Professional School Counseling [Online], vol. 22, issues 1 , available https://journals.sagepub.com/doi/full/10.1177/2156759X19848331.

[15] J.W. Chandler, J.J. Burnham, M.E.K. Riechel, Dahir, C.A., Stone, C.B., Oliver, D.F., Davis, A.P. and Bledsoe, K.G., Assessing the Counseling and Non-Counseling Roles of School Counselors. Journal of School Counseling, vol. 16, issue 7, p.n7, 2018.

[16] J.K. Kok, and S.K. Low, "Proposing a collaborative approach for school counseling". International Journal of School \& Educational Psychology, vol. 5, issue 4, pp.281-289, 2017.

[17] M.Y.I. Adesti, N. Hidayah, and D.H. Rahman, "Flashbacks of Guidance and Counseling Services in Indonesia". In 6th Int. Conf. on Education and Technology, 2000, (pp. 12-16) online Available: https://www.atlantis-press.com/proceedings/icet-20/125947650.

[18] Y.F. Sakinah, N. Hidayah, and D.H. Rahman, "Importance Meaning of the Counselor's Identity Towards Assessment and Performance in School," in 6th Int. Conf. on Education and Technology (ICET 2020) (pp. 398-401), Atlantis Press, Dec. 2020.

[19] W.P. Helker, A.A. Schottelkorb, D. Ray, "Helping students and teachers CONNECT: An intervention model for school counselors," Journal of Professional Counseling: Practice, Theory \& Research, vol. 35, issue 2, pp. 31-45, 2007.

[20] C. Dimmitt, "Why evaluation matters: Determining effective school counseling practices," Professional School Counseling, vol. 12, issue 6 , pp.395-399, 2009

[21] D.K. Buchanan, B.S. Mynatt, and M. Woodside, "Novice school counselors' experience in classroom management," The Journal of Counselor Preparation and Supervision, vol. 9, issue 1, 2017, available: https://repository.wcsu.edu/jcps/vol9/iss 1/2/

[22] N. ErlinaYaumas, S. Syafril, N.M. Noor, Z. Mahmud, J. Umar, I.S Wekke, and T. Rahayu, "The Importance of Counselling Basic Skills for the Counsellors," International Journal of Pure and Applied Mathematics, vol. 119, issue 18, pp.1195-1207, 2018.

[23] L.F. Holman, J. Nelson, and R. Watts, "Organizational Variables Contributing to School Counselor Burnout: An Opportunity for Leadership, Advocacy, Collaboration, and Systemic Change,' Professional Counselor, vol. 9, issue 2, pp.126-141, 2019.

[24] B.M. Bobik, "The importance of interpersonal skills in the work of a school counselor," Journal of Modern Science, vol.44, issue 1, pp.43-62, 2020 . 